\title{
MORPHOLOGICAL STUDY ON THE PERICYTES OF GOAT'S PLACENTOMAL CAPILLARIES
}

\author{
Akram Y. Yasear and Salha Zoubi \\ Department of Anatomy and Histology, Faculty of Mcdicine, \\ Garyounis University, Benghazi, Libya
}

\section{INTRODUCTION}

Pericytes are connective tissue cells associated abluminally with capillary and postcapillary venules. They share a common basal lamina with endothelial cells (Majno, 1965; Schor et al., 1995). Such microvessels are involved with the exchange of material and cxtracellular space (Nehls and Drenckhahn, 1993). Pericytes were first described in the nictitating membrane of the frog by Rouget (1873), and have been seen surrounding capillarics in a wide variety of tissues (Zimmerman, 1923; Majno, 1965; Lunam and Roger, 1981; Sims, 1986; Hirschi and D'Amore, 1996; Sundberg et al., 1996; Wisse et al., 1996). The most probable function for pericytes is the regulation of capillary flow by their contraction (Epling, 1966; Rhodin, 1968; Wieble, 1974; Tilton et al., 1979). A possible functional role of the pericytes is the control of material cxchange through the vessel wall (Imayama and Urab, 1984) and its participation in angiogenesis has been proposed (Crocker et al., 1970; Schor et al., 1995). A further role that has been attributed to pericytes is to stabilize the capillary wall (Cohen et al., 1980; Frank et al,, 1990; Jeon et al., 1996). In rat uterus, the increase in pericytes coincides with the time of implantation (Lunam and Roger, 1983). Steven and Samuel (1979) have suggestcd that there are few pericytes associated with the maternal capillaries in sheep placenta to perform an important regulatory function on the transport of unaterial from the mother to the fetus. However, Yasear et al. (1987) found a considerably large number of pericytes in association with the maternal microvessels in sheep placenta throughout pregnancy. In the goat's placenta, the materno-fetil interlace is characterized by the presence of syncytial tissue covering the maternal side of placentomes. The plcentomes are ruminant-specific fetomaternal contact zones characterized by 
the presence of microvillar junction between syncytium and fetal trophoblastic layer (Steven, 1975; Wooding and Flint, 1994). Due to the lack of information on the distribution of pericytes in the goat's placenta the present study was initiated to evaluate the distribution of the pericytes surrounding the maternal capillaries which arc located close to the syncylium, i.e. those most closely involved in the materno-fetal exchanges throughout pregnancy.

\section{MATERIALS AND METHODS}

The gestation period in the goat is 150 days. Pregnant uteri from twenty-one goats of known mating dates were used in this study at seven different stages of pregnancy. The time of collection was day 19 day post coitum (dpc) ( 2 goats), day $35 \mathrm{dpc}$ (4 goats), day $53 \mathrm{dpc}$ ( 3 goats), day $80 \mathrm{dpc}(5$ goats), day $95 \mathrm{dpc}$ ( 2 goats). day $120 \mathrm{dpc}$ ( 3 goats), and day $135 \mathrm{dpc}$ ( 2 goats). The uteri were removed after killing the animals with pentobarbitone sodium and then perfused via the middle uterine artery with Karnovsky's fluid (Karnovsky, 1965) in $0.1 \mathrm{M}$ phosphate buffer pH 7.2 plus $2 \%$ sucrose for 20 minutes. The plcentomes (containing the fetal tissue and maternal tissue) were then cut up into "matchstick" size, each of which ran the full depth of the placentomc. The samples collected were further placed in fresh fixative for 2 hours at $4 \mathrm{c}$. the tissues were then postfixed in $2 \%$ osmium tetroxide in 0.1 phosphate buffer $\mathrm{pH} 7.2$ for one hour at room temperature. The samples were then dehydrated in ascending grades of alcohol, soaked in propylene oxide and embedded in Epon / Araldite. Semithin serial sections were cul, using an LKB 111 ultratome, at one micron thickness from five blocks of tissue per animal and stained for light microscopy with $1 \%$ toludine blue. Capillary profiles werc counted using light microscope. in the caruncular stroma (which represents the matemal side of the placentome) and scored for the presence or absence of recognizable pericyters. A rotal of 100 capillaries were counted per animal using five sections, one from each block. For electron microscopy, 40 - $70 \mathrm{n}$, ultrathin sections were placed onto copper grids. They were stained with uranyl acetate and lead citrate and examined in Zeiss EM-10 electron microscope. Nonpregnant uteri from six animals were used as control for comparison and processed for microscopy as mentioned above. The means of the percentage of the pericyte counts were calculated. In adition. the Odds ratio principle for means of capillaries with pericytes and without was calculated. 


\section{RESULTS}

At the electron microscopic level the pericytes were identified as perivascular cells surrounded by their own basal lamina. The basal laminae of the pericytes and those of endothelial cells often fuse to form a common basal lamina (Figs. 1, 2). Other stromal cells (the fibroblast - like cells) of the caruncular endometrial tissue were not included within this basal lamina. The results of pericytic counting at all stages of pregnancy and those of the nonpregnant animals arc summarized in Table (1). There was no significant ifference between animals and blocks of the same stages of pregnancy.

At the implantation site on ay $19(\mathrm{dpc})$ the pericytic profiles associated with capillaries in the subsyncytial region were more obvious than those of the capillaries in the rest of endometrial caruncular tissue. Progressive increase in the number of pericytes was noted as pregnancy advances from day 35 (dpc) till day $135(\mathrm{dpc})$. At day $35(\mathrm{dpc})$, the fetal villi were well underway advancing further down into the endometrial tissue. At the stage 35 (dpc), the stromal cells of the endometrium (fibroblast - like cells) were seen in the area around the maternal capillaries (Fig. 1). Between days 80 and $95(\mathrm{~d} \rho \mathrm{c})$ the fetal villi advanced further and further down into the maternal (endometrial) tissue. Associated with that, the numbers of pericytes were significantly increased (Table 1 ). In the late stages of pregnancy on day $120(\mathrm{dpc})$ and day $135(\mathrm{dpc})$ the number of pericytes was higher than those of the preceding days (Table 2). Their distribution appeared to be uniform across the maternal side of the placenta.

During all stages of pregnancy included in this study, the cytoplasm of the pericytes associated with the maternal capillaries involved in the materno-fetal exchange contained well-developed rough endoplasmic reticulum and Golgi apparatus. The free ribosomes and polyribosomes werc abundantly distributed in the cytoplasm of the pericytes (Fig. 2). Microfilaments were abundantly distributed in the cytoplasm of the pericytes especially under their membrane (Fig. 3). Glycogen particles were also seen (Fig. 4). During the period from day $80(\mathrm{dpc})$ to day $135(\mathrm{c} x)$ pericytes were the only cell types seen to intervene between the maternal capillaries and the syncytium (Fig. 5). Besides, the distance between the maternal capillaries and the syncytium was greatly decreased (Fig. 5). On the other hand, no trace of fibroblast like cells could be seen between the maternal capillaries and syncytium despite the thorough search using Semithin and ultrathin sections. 
Pericytes around the cndometrial capillaries of the nonpregnant goats were infrequently seen (Fig. 6). Only 15\% of them were showing pericytic profiles. Moreover, the cytoplasm of the pericytes in the nonpregnant animals showed less activity than that of the pregnant animals.

Table 1 : The percentage of the means of capillaries with and without pericytes coverage.

\begin{tabular}{|c|c|c|}
\hline Day of pregnancy & Number of goals & \% of capillaries with pericytes \\
\hline 19 & 2 & 32 \\
\hline 35 & 4 & 51 \\
\hline 53 & 3 & 54 \\
\hline $\mathbf{8 0}$ & 5 & 69 \\
\hline 95 & 2 & 72 \\
\hline 120 & 3 & 77 \\
\hline 135 & 6 & 87 \\
\hline Nompregnant goals & 6 & 15 \\
\hline Total & 27 & \\
\hline
\end{tabular}

Table 2 : Odds ratio of 9.34 means that an animal with pregnancy group is 9.34 times morc likely to have pericytes coverage than an animal without.

\begin{tabular}{|l|c|c|c|}
\hline & \multicolumn{2}{|c|}{ Capillaries With Pericytes } & \\
\hline Pregnant & & Present & Absent \\
\hline & Yes & 63 & 37 \\
\hline & No & 15 & 85 \\
\hline
\end{tabular}



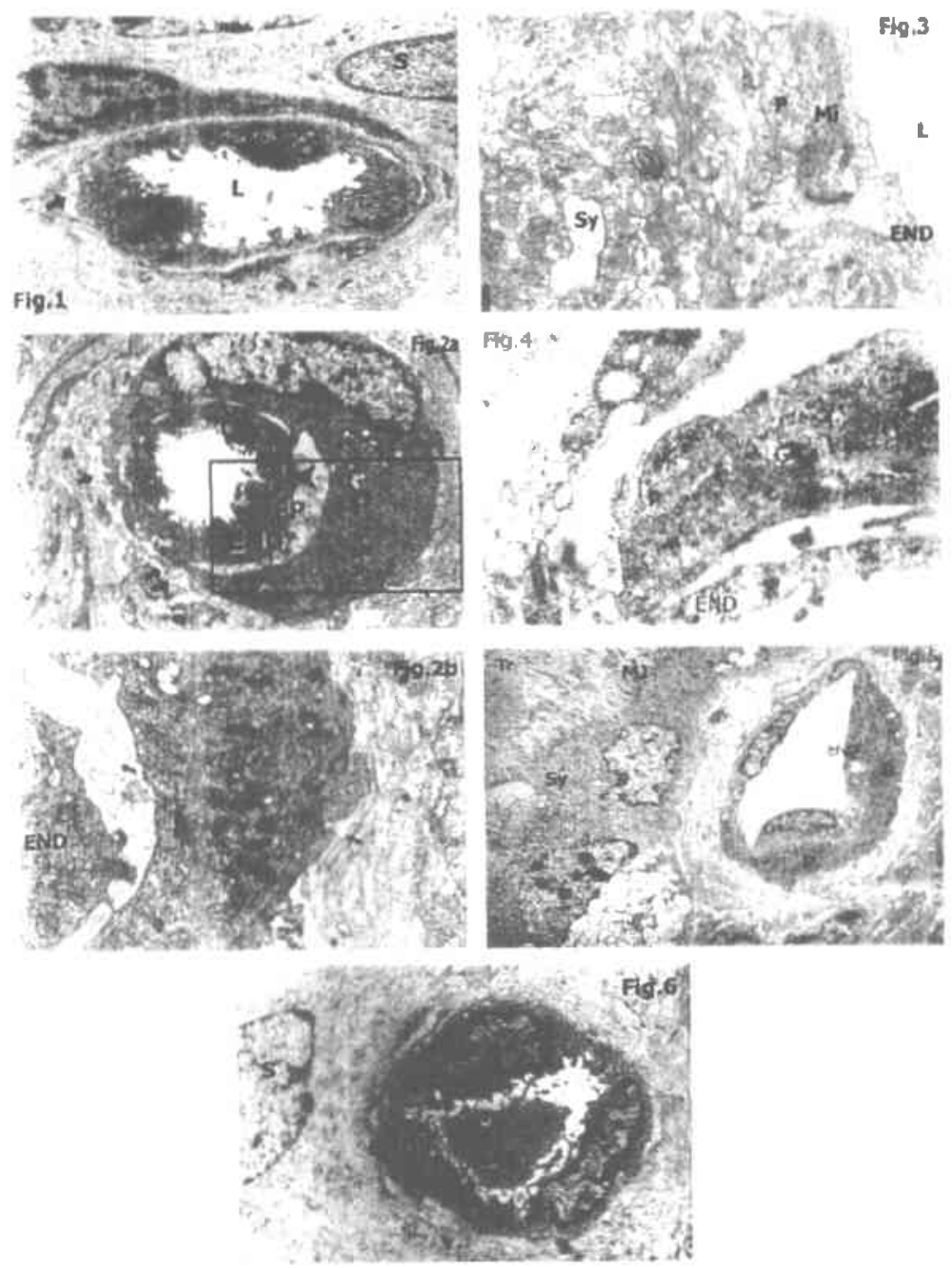

Fig. (1) : Maternal capillary at day 35 dpe showing pericyte (p) partially enclosing the cndothelium (END). Note the presence of hasal lamina (arrow), stromal cells (fibroblast like cell) (s) lumen of the capillary (L).

$(x 4800)$

Fig. (2-a) : Maternal capillary at day $53 \mathrm{dpe}$ with pericyte (P) totally enclosing the enothelium (END).

Notice the well-developed cytoplasmic otganelles. Notice also the common basal lamina (arrow) which diverges (double arrow) to enclose the endothelium and pericytes.

$(x 4800)$

Fig. (2 - b) : Inset of figure 2 - a showing well-developed cytoplasmic organelles. Notice the pericyte (p), endothelium (END) and basal lamina (arrow).

(x 9000$)$

Fig. (3) : Pericytic process with microfilaments (Mi). Lumen of capillary (L), endothelium (END) and syncytium (Sy) at day $120 \mathrm{dpc}$.

(x 13.000)

Fig. (4) : Segment of pericyte (P) surrounding the endothelium (IND) of matemal capillary at day 120 dpc. Note the accumulation of glycogen particles $(\mathrm{G})$ inside the cytoplasm.

(x 15.000)

Fig. (5) : Matemal capillary at day $80 \mathrm{dpc}$ showing pericyte (P) investing the endothelium (PND). The space belween the capillary and syncytium (Sy) no longer contains the fibroblast - like cells of the caruncular endometrial tissue. Notice the microvilhar junction (MJ) between syncytium and trophoblastic layer (Tr) of the fetal side of the placenta.

(x 5200)

Fig. (6) : Canuncular endometrial capillary of non-pregnant goat where pericytes were infrequently seen. Note the endothelium (END) and fibrublast - like cell (S). 


\section{DISCUSSION}

The elcctron microscopic results of the present study demonstrated for the first time the presence of the pericytes as frequent perivascular cells closely investing the maternal capillaries which are closcly involved in materno-fetal exchange in the goat placenta. The pericytic frequency initially increased during the implantation time at day $19 \mathrm{dpc}$ (Wango et al., 1990) as compared with nonpregnant goats. That would correspond with the physiological adaptation of maternal tissue to accept the recently implanted blastocysts. A similar conclusion has been reported elsewhere for the pregnant rat uterus during the implantation time (Lunam and Rogers, 1983).

Pericytes are considered to be required for normal microvasculature stability and function (Sims, 1986). In analogy with the importance of pericytes in angiogenesis which is occurring in many organs (Nehls et al., 1992; Abramsson et al., 2003), pericytes of maternal side of goat's placenta are equally important in the normal development of maternal microvasculature to cover the demand for nutrition of the growing fetus. The increase in uterine mass during pregnancy requires the establishment of sufficient blood supply. Pericytes deficiency, as seen in abnormal pregnancy in mice (Lindahl et al., 1997), promotes a range of microvasculature changes such as endothelial hyperplasia, tortuosity, leakage and rupture, lcading to microhaemorrhage and edema in late gestation.

During the period from day 19 (dpc) to day $53(\mathrm{dpc})$, the fibroblast - like cells were seen to interpose between the maternal capillaries and their associated pericy. tes on one side and the syncytium on the other side.

The period from day 80 to 135 (dpc) was marked by the increase in thickness of maternal connective tissue intervening between the maternal capillaries and syncytium, in order to facilitate matcrno-fetal exchange (Steven and Samuel, 1979). It is obvious that the extent of pericytic recruitment during this period of pregnancy is much more than that of the pervious period and the nonpregnant animal. In pregnancy. the developing embryo would not be able to attain a radius of greater than 1 or 2 mm unless a hyperemic response was induced in the uterus (Bartles and Baumann, 1972). To have the hyperemic response a process of angiogenesis in the maternal microvasculature must be established (Nehls and Drenckhahn, 1993). The presence of microfilament in the cytoplasm of pericytes of the present study suggests its con- 
tractility and rolc in adjusting capillary blood flow (Kelly et al., 1987; Nehls and Drenkhahn, 1991) which is important in regulation of microperfusion at the distal location in vasculature. That was considered as an effective mechanism to efficiently distribute oxygen and nutrient greatly nceded by the fetus (Kawamura et al., 2002).

The most probable candidate for the origin of the pericytes is the fibroblast like cells nearest to maternal capillaries which may migrate toward them and transform into pericytes. Rhodin and Fujuta (1989) as well as Stein et al. (1996) have provided the support for the idea that pericytes could evolve from perivascular fibroblasts. Thus. according to Grosser's classification (1909 and 1927), who defined the placenta by the number of layers intervening between the maternal and fetal circulation, pericytes are considered as the only representative for the conncctive tissue cells interposed between the maternal capillarics and the syncytium. Furthermore. the position of pericytes around the maternal microvasculature in the goat's placenta was a reminder of the position of binucleated cells which were found in equivalent position in the dog placenta (Amoroso, 1952; Mossman, 1988). Pericytes like the binucleated cell never form a coherent layer as the extensive decidual cells development charactcrizes hemochorial placentae (Parr an Parr, 1989).

Moreover, the patterns of distribution of pericytes coupled with the presence of active well - differentiated cytoplasm suggest that they may play a role in production of specific secretion, in order 10 maintain the delicate balance belween fetal and maternal tissues.

\section{SUMMARY}

Pericyles are connective tissue cells associated abluminally with capillaries and postcapillary venules. They can be found in goat's placenta associated with matemal microvasculature. In this study, twenty - scven pregnant and nonpregnant goat's uteri were examined quantitatively and electron microscopically to assess pericytes association with maternal capillarics. Capillaries with pericytes increased from $15 \%$ in the nonpregnant animal $1032 \%$ during the implantation period. This represents an adaptation of the matcrnal tissue at the site of implantation. Pericyles were observed in $77 \%$ of the cross sectional capillary profiles examined during the day 135 (dpe). The penetration of fetal villi down into the maternal tissue in the successive slages of pregnancy appeared to have a role in the transformation observed in the maternal 
pericytes. The maternal pericytes exhibited a view of active cytoplasm. The prescnce of microfilaments in the cytoplasm of pericytes suggested a regulatory function in the maternal circulation. From day 80 (dpc) onwards pericytes were shown to be the only connective tissue cell type present in the area betwcen the syncytium (covering the maternal tissue) and the maternal capillary endothelium.

\section{REFERENCES}

1. Abramsson, A.; Lindblom, P. and Betshltz, C. (2003) : Endothelium and nonendothelial sources of PDGF - B regulate pericyte Recruitment and influence vascular pattern formation in Tumors. J. Clin. Invest., 112 : 1142 - 1151.

2. Amoroso, E.S. (1952) : Placentation, In Marshall's Physiology of reproduction Parkes, A.S. (ed) Longmans Green, London, Vol. II, 127 - 311.

3. Bartels, N. and Baumann, F. (1972) : Preplacental gas exchanges; In Respiratory gas exchange and blood flow in the placenta. Eds. Longo L.D. and Bartels N., U.S. government Printing office, Washigton, D.C., 1 - 12.

4. Cohen, M.P.; Frank, R.N. and Kalifa, A.A. (1980) : Collagen production by Cultured retinal capillaries pericytes. Invest. Ophthamol. Vis. Sic., $19: 90$ - 94.

5. Crocker, D.J.; Murade, T.M. and Geer, J.C. (1970) : Role of the pericyte in Wound healing. Exp. Mol. Patho., $13: 51$ - 65.

6. Epling, G.P. (1966) : Electron microscopic observation of pericytes of small blood vesscls in the lungs and hearts of normal cattle and swine. Anat. Rec., 155 : $512-529$.

7. Frank, R.N.; Turezyn, T?J. and Das, A. (1990) : Pericyte coverage of Retinal and cerebral capillaries. Invest. Ophıhalmol. Vis. Sci., 31 : 999 - 1007.

8. Grosser, O. (1909) : Verlagechende anatomie und entwicklugsgesch der Einaute und der placenta. Vienna, Brusuller.

9. Grosser, O. (1927) : Fruhentwicklung, elhautbilduung und placentation Des menschen und der sangetlerre. Munich, Begmann.

10. Hirschi K.K. and D'Amore, P.A. (1996) : pericytes in the microvasculature. Cardiovasc. Res., 32 : 687 - 689.

11. Imayama, S. and Urabe, H. (1984) : Pericytes on the dermal microvascul ature of the rat skin. Anat. Embryo., $169: 274$ - 274.

12. Jeon, H.; Ono, M.; Kumagia, C.; Miki, K.; Morita, A. and Kitagawa, Y. (1996) : Pericytes from microvessels fragment produce type IV Collagen and multiple lamina isoforms. Biosci. Biotech. Biochem., $60: 856$ - 861 . 
13. Karnovsky, M.J. (1965) : A formaldehyde - gluteraldehyde fixative of high Osmalarity for use in electron microscopy. J. Cell. Bio.. 27 (2) : 137A - 138A.

14. Kawamura, H.; Oko, H.; L., Q.; Sakagami, K. and Purp, D.g. (2002) : Endothelium - Induced changes in physiolofy of retinal pericytes. Invest. Ophthalmo. Vis. Sci., 43 : 882 - 888.

15. Kelly, C.D.; D'Amore, P.; Hechtman, H.H. and Shepro, D. (1987) : Microvascular pericyte contractility in vitro : comparison with other cells of the vascular wall. J. Cell Biol., $104: 483-490$.

16. Lindahl, P.; Johansson, B.R.. Leveen, P. and Betsholtz, C. (1997) : Pericyte loss and microaneurysm formation in PDGF - B deficient mice. Science, 227 : $242-245$.

17. Lunam, C. and Rogers, A.W. (1983) : Pericytes in the stroma of the rat uterus. J. Reprod. Fertil., $63: 267$ - 270.

18. Majno, (j. (1965) : Ultrstructure of the vascular membrane; In Hand book of physiology, Hamilton. W. F. an Dowie P. (eds), Section 2 : Circulation, Amercan physiological Society, Washington, $2293-2357$.

19. Mossman, H.W. (1987) : Vertebrate fetal membranes; In comparative Ontogeny and morphology. Phylogenic significance; basic Functions. Rescarch opportunities. Basingstoke. Mcmillan.

20. Nehls, V. and Drenckhahn, D. (1991) : Demonstration of actin filaments trec fibers in microvascular endothelial cells in silu. Microvascular Res.. $42: 103$ 112.

21. NehIs, V.; Danzer, K. and Drenckhahn, D. (1992) : Pericyle involvement in capillary sprouting during angiogenesis in situ. Cell tiss. Res. $270: 469-474$.

22. Nehls, V, and Drenckhahn, D. (1993) : The versatility of microvascular, pericytes from mesenchyme to smooth muscle. Histochemistry, $99: 1-12$.

23. Parr, M.B. and Parr, E.L. (1989) : The implantation reaction; In Biology of uterus. Wynn R.M. and Jollic W.P. (eds), Plenum Press, New York, 233 - 273.

24. Rlondin, J.1.G. (1968) : Ultrastruclure of mammalian venous capillaries, Venules andsmall collecting venules. J. Ultrast. Res., $25: 452$.

25. Rhodin, J.A.G. and Fujita, H. (1989) : Capillary growth in the mesentry of normal young rats. J. Submicroscop. Cytol.. $21: 1-34$.

26. Rouget, C. (1873) : Memoire sur le development la structure et les Proprietes physiologiques es capillaries sanguine et lymphatiques. Arch. Physiol. Norm. Path., 5 : 603 - 663. 
27. Schor, A.M.; Canfield, A.E.; Sutton, A.B.; Arciniegas, E. and Allen, T.D. (1995) : Pericyte differentiation. Clin. Orthop., 313 : 81 - 91.

28. Sims, D.E. (1986) : The pericyte - A review. Tiss. Cell, $18: 153$ - 174.

29. Stein, J.; Drenckhahn, D. and NehIs, V. (1996) : Development of pericyte like cells during angiogenesis in quail chick chimeras as detected by combined feulgen reaction and immunohistochemistry. Anat. Anz., 178 (2) : 153 - 158.

30. Steven, D.H. (1975) : Comparatuve placentation : Essay in structure and function. Chapter 2: Anatomy of placental barrier, Academic press, London, 25 - 57.

31. Steven, D.H. and Samuel, C.A. (1979) : The anatomy of placental transfer in placental transfer. Chamberlain G.V.P. and Wlikinson A.W. ed., Tunbridge well, Pitman Medical, 1 - 14.

32. Sundberg, C.; Ivarsson, M.; Gerdin, B. and Rubin, K. (1996) : Pericytes As collagen producing cells in excessive dermal scarring. Lab. Invest. 74 (2) : 452 466.

33. Tilton, R.G.; Kilo, C. and Williamson, J.R. (1979) : Pericyte - endothelial Relationships in cardiac and skeletal muscle capillaries. Microvasc. Res., $18: 325$ 335.

34. Wango, E.O.; Wooding, F.B.P. and Heap, R.B. (1990) : The role of trophoblast Binucleated cells in implantation in the goat : A morphologi cal study. J. Anat., $171: 241-257$.

35. Weible, E.R. (1974) : On pericytes; particularly their existence on lung capillaries on lung capillary. Microvas. Res., $8: 218-235$.

36. Wisse, E.; Braet, F.; Luo, D.; De Zanger, R.; Jans, D.; Crabbe, E. and Vermoesen, A. (1996) : Structure and function of sinusoidal Lining cells in liver. Toxicol. Patho, 24 (1) : 100 - 111.

37. Wooding, F.B.P. and Flint, A.B.F. (1994) : Placentation; In Marshall's physiology of reproduction Lamming, G.E. ed., Chapman \& Hall, London, Part I. Vol. III, $233-460$.

38. Yasear, A.Y.; Moore, R.E. and Arbuyhnott, F.R. (1987) : Pericytes in sheep placenta. Irish. J. Med. Sci., $158: 52$ - 53.

39. Zimmermann, K.W. (1923) : Der feinere bau der blutcapillaren. Z. Anat. Entwick., $68: 3$ - 109. 


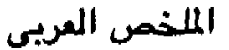

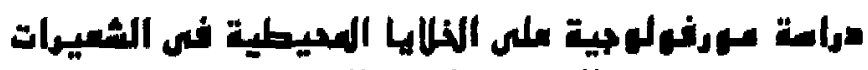

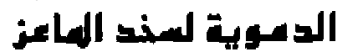

\section{أكرم يهاف ياسر - صالة الزهبه \\ قسم التشريح والانسجة - كلية الطب - جامعة تاريونس - بنغانى - ليييا}

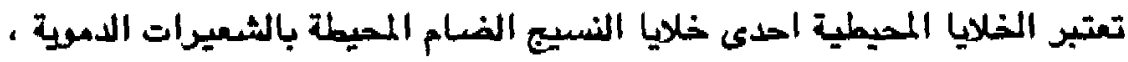

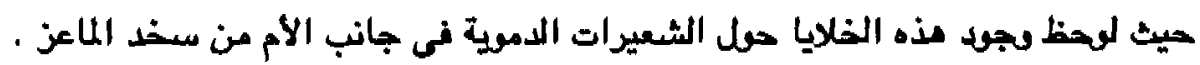

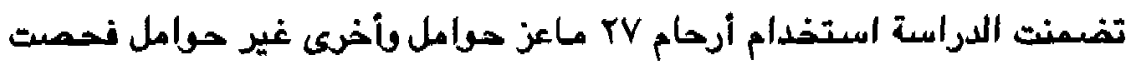

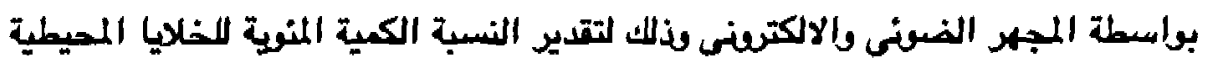

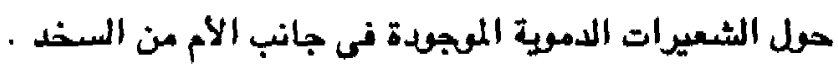

وقد لوخظ زيادة فى نسبة الشعيرات الدموية الحاوية على خلايا محيطية حمل

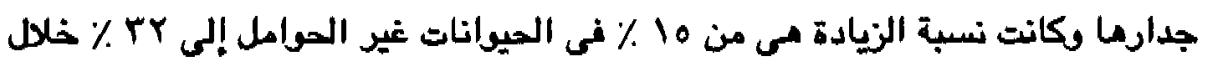

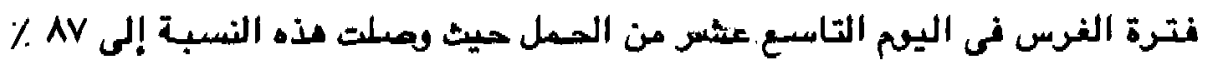

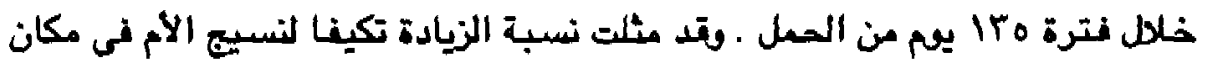

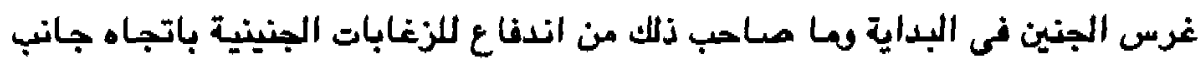

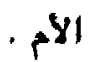

كما لوحظ أيضـا الفاعلية النشطة لسيتو بلازم الخلايا المحيطية خلال نترات

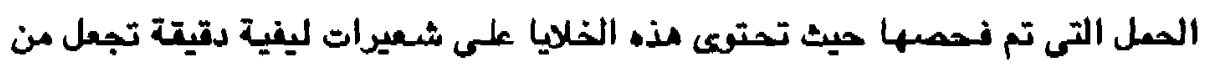

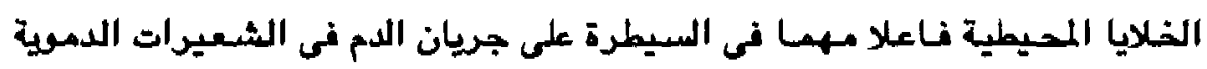

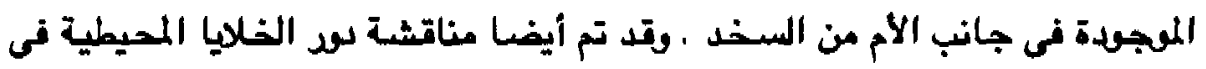

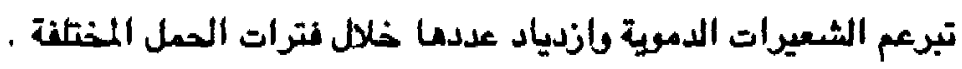

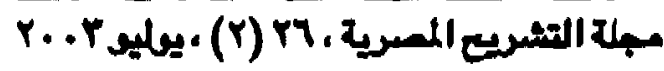

